\title{
Effects of chemical treatments and environmental factors on seed dormancy and germination of shepherd's purse (Capsella bursa-pastoris (L.) Medic.)
}

\author{
Mohammad Rezvani ${ }^{1}$, Faezeh Zaefarian ${ }^{2}$ and Vajihe Amini ${ }^{2}$
}

Received: August 27, 2013. Accepted: February 17, 2014

\begin{abstract}
Shepherd's purse (Capsella bursa-pastoris) is a problematic weed in citrus orchards and crop fields in northern Iran. In a series of laboratory and greenhouse experiments, we evaluated the effects that treatment with gibberellic acid $\left(\mathrm{GA}_{3}\right)$ and potassium nitrate $\left(\mathrm{KNO}_{3}\right)$, as well as environmental factors, including temperature, the duration of pre-chilling (wet and dry), drought stress, salt stress, $\mathrm{pH}$, and sowing depth, have on seed dormancy breaking and germination in C. bursa-pastoris. Treatment with $\mathrm{GA}_{3}$ strongly stimulated germination of C. bursa-pastoris in conditions of light/ dark and continuous darkness. The germination rate was highest (40.08\%) for seeds treated with $400 \mathrm{ppm}$ of $\mathrm{GA}_{3}$ in the light/dark condition. Treatment with $\mathrm{KNO}_{3}$ did not significantly influence seed germination. Longer wet pre-chilling promoted germination and was more successful in seed dormancy breaking than was dry pre-chilling. Seed germination occurred at $10-30^{\circ} \mathrm{C}$ and within a range of $\mathrm{pH}$ of 3-11. Drought and salt stress both strongly inhibited germination. Seedling emergence decreased in proportion to sowing depth. The rates of C. bursa-pastoris germination and seedling emergence were highest for seeds on the soil surface.
\end{abstract}

Key words: Drought and salt stress, gibberellic acid, light, temperature, sowing depth

\section{Introduction}

Shepherd's purse (Capsella bursa-pastoris (L.) Medic.), a member of the family Brassicaceae, is an annual winter weed that occurs in Asia, Africa, Australia, Europe, North America, and South America (Holm et al. 1979). In Iran, C. bursapastoris is often found in citrus orchards, as well as fields of wheat (Triticum aestivum L.) and canola (Brassica napus L.). It is a prolific seed producer, a single C. bursapastoris plant being able to produce several thousand seeds (Karimi 2001).

Seed germination is strongly affected by seed dormancy. Seed dormancy is a complex mechanism that has evolved to ensure future seed germination and plant establishment. The dormancy of seeds is controlled by environmental factors that ensure synchronization with the optimal growing season (Baskin \& Baskin 1989). Breaking dormancy or inducing germination is influenced by several factors, including alternating temperatures, light, and nitrate (Bouwmeester \& Karssen 1992; 1993). In addition, growth regulators such as gibberellic acid $\left(\mathrm{GA}_{3}\right)$ can induce seed germination without after-ripening in plants (Bewley \& Black 1994).

Various environmental factors, such as light, temperature, soil moisture (Chauhan \& Johnson 2010), and pH, interact to influence seed germination (Koger et al. 2004). Temperature and light play critical roles in regulating seed germination (Chauhan et al. 2006a). A non-optimal temperature could result in the inhibition of germination and ultimately in the induction of dormancy (Toorop et al. 2011). Light can induce dormancy in positively photoblastic seeds when those seeds are sown in the soil (Toorop et al. 2008). Sowing depth also influences germination and seedling establishment (Koger et al. 2004).

The principal Capsella bursa-pastoris strategy for survival and dispersal in agroecosystems is prolific seed

\footnotetext{
${ }^{1}$ Department of Weed Science, Qaemshahr Branch, Islamic Azad University, Qaemshahr, Iran Postal address: Department of Weed Science, Agricultural Science and Natural Resources College, Islamic Azad University, Qaemshahr Branch, P.O. box 163, Tel: +981512239229, Fax: +981232253536

${ }^{2}$ Department of Agronomy, Sari Agricultural Sciences and Natural Resources University, Mazandaran, Iran

${ }^{3}$ Author for correspondence: m_rezvani52@yahoo.com
} 
production. Therefore, an understanding of the dormancy breaking methods and germination requirements may help us in predicting emergence and its potential behavior in field crops, which could be critical in devising effective control methods. The objectives of this study of Capsella bursa-pastoris were to determine the effects of gibberellic acid $\left(\mathrm{GA}_{3}\right)$ and potassium nitrate $\left(\mathrm{KNO}_{3}\right)$ on seed dormancy breaking; to investigate the effects that environmental factors, including temperature, light, pre-chilling duration, salt stress, drought stress, and $\mathrm{pH}$, have on seed germination; and to assess the effect of sowing depth on seedling emergence.

\section{Material and methods}

\section{Seed collection}

Capsella bursa-pastoris seeds were collected from naturally ripened pods of intact plants growing in a wheat field at Qarakheyl Crop Research Station ( $\left.36^{\circ} 27^{\circ} \mathrm{N} ; 52^{\circ} 46^{\prime} \mathrm{E}\right)$, within the province of Mazandaran, Iran, in the summer of 2010. Seeds were removed from pods and stored in paper bags at room temperature $\left(20 \pm 5^{\circ} \mathrm{C}\right)$ until use. The weight of 1000 C. bursa-pastoris seeds was $0.08 \mathrm{~g}$. Before the experiments, seed viability was tested by immersion of the seeds in $1 \%$ tetrazolium chloride solution (Peters 2000). The tetrazolium chloride test showed that approximately $98 \%$ of the seeds were viable.

\section{General germination}

Fifty seeds were placed in a 9-cm plastic petri dish containing one filter paper disk moistened with $5 \mathrm{ml}$ of distilled water or test solution including $\mathrm{GA}_{3}, \mathrm{KNO}_{3}$, sodium chloride $(\mathrm{NaCl})$, polyethylene glycol, and $\mathrm{pH}$ buffer solutions. Dishes were sealed with a plastic film and placed in a germinator (X630; Fater Electronic, Tehran, Iran) set at $25 / 15^{\circ} \mathrm{C}$ (day/ night). Light was provided by fluorescent lamps to produce a light intensity of $300 \mu \mathrm{mol} \mathrm{m}^{-2} \mathrm{~s}^{-1}$. The photoperiod was set at $12 \mathrm{~h}$ (day/night) for all germination tests except continuous darkness. For the germination test in continuous darkness, the petri dishes were wrapped in two layers of aluminum foil and seed germination was quantified only after 4 weeks. Germinated seeds were counted at 4 weeks after the start of tests. Seeds were classified as germinated when the cotyledons and radicle emerged from the seed coat.

\section{Seed dormancy breaking}

\section{Effects of light and $\mathrm{GA}_{3}$}

Germination of Capsella bursa-pastoris seeds in response to $0,25,50,100,200,400,600$, and $800 \mathrm{ppm}$ of $\mathrm{GA}_{3}$ was evaluated in the 12/12-h light/dark and continuous darkness conditions.

\section{Effect of $\mathrm{KNO}_{3}$}

The effectiveness of $\mathrm{KNO}_{3}$ in breaking the dormancy of Capsella bursa-pastoris seeds was evaluated at concentrations of $0,0.01,0.5,2,5$, and $10 \mathrm{mmol}$ of $\mathrm{KNO}_{3}$ in the 12/12-h light/dark condition.

\section{Effect of the duration of pre-chilling (wet and dry)}

The effect of pre-chilling duration on the promotion of seed germination of Capsella bursa-pastoris was studied by placing seeds in wet or dry conditions for 15,30 , and 45 days at $5 \pm 1^{\circ} \mathrm{C}$. For wet pre-chilling treatments, seeds were wrapped in moistened towels. After pre-chilling, seeds were set to germinate immediately.

\section{Environmental factors}

\section{Effects of constant temperature and light}

The effect of five constant temperatures $(10,15,20$, 25 , and $30^{\circ} \mathrm{C}$ ) was evaluated in the $12 / 12$-h light/dark and continuous darkness conditions to determine the response of seed germination to variations in temperature and light.

\section{Effect of drought stress}

To evaluate the effect of drought stress, aqueous solutions with osmotic potentials of $0,-0.1,-0.25,-0.5,-1$ and -1.5 MPa were prepared by dissolving 0, 99.4, 157.1, 222.2, 314.2, and $384.8 \mathrm{~g}$, respectively, of polyethylene glycol 8000 (Merck, Darmstadt, Germany) in 1 L of distilled water (Michel 1983).

\section{Effect of salt stress}

The effect of salt stress on Capsella bursa-pastoris seed germination was tested by treating seeds in solutions of 0 , $10,20,40,80$, and $160 \mathrm{mM}$ sodium chloride (Merck).

\section{Effect of $\mathrm{pH}$}

The effect of $\mathrm{pH}$ on seed germination was determined

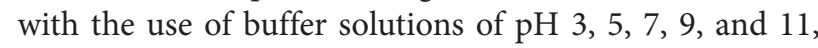
prepared according to Chachalis \& Reddy (2000).

\section{Effect of seed sowing depth}

Fifty Capsella bursa-pastoris seeds were planted in soil in 15-cm-diameter plastic pots at depths of $0,0.5,1,2$, and 4 $\mathrm{cm}$. Control pots were assumed to have no background seed bank of C. bursa-pastoris in the soil. No C. bursa-pastoris seedlings emerged in the control pots by 45 days after sowing, suggesting there was no background C. bursa-pastoris seed bank in their soil.

In this experiment, we used a silty soil containing $29.4 \%$ clay, $51.4 \%$ silt, and $19.2 \%$ sand, and $0.41 \%$ organic carbon, 
with a $\mathrm{pH}$ of 7.8. Pots were irrigated as needed to maintain soil moisture at field capacity. The greenhouse temperature was set at $25 / 15^{\circ} \mathrm{C}$ (day/night) with a natural photoperiod. Seedling emergence was defined as the appearance of the two cotyledons, and emerged seedlings were counted at 45 days after planting.

\section{Statistical analyses}

Seed germination and seed planting depth experiments were conducted in a complete randomized manner with three replicates and were performed in duplicate. We performed ANOVA of the arcsine transformed data obtained as percent germination. Means were separated by Fisher's least significant difference test or standard error bars at the 0.01 probability level.

For the salt stress experiment, we used regression analysis to determine the response of the data. To that end, we employed a functional three-parameter logistic model (Kleemann et al. 2007), plotted to the seed germination rates (\%) at different osmotic potentials:

$G(\%)=G_{\max } /\left[1+\left(x / x_{50}\right)^{G_{\text {rate }}}\right]$

where $G$ indicates the total seed germination (\%) at osmotic potential $x, G_{\max }$ is the maximum seed germination (\%), $x_{50}$ is the osmotic potential for $50 \%$ inhibition of the maximum seed germination, and $G_{\text {rate }}$ is the slope of the curve.

\section{Results and discussion}

\section{Seed dormancy breaking treatments}

$\mathrm{GA}_{3}$

Treatment with $\mathrm{GA}_{3}$ had a significant influence on Capsella bursa-pastoris seed germination (Tab. 1), strongly stimulating germination in the $12 / 12$-h light/dark and continuous darkness conditions. The proportion of seeds germinated was highest $(40.08 \%)$ among those treated with $400 \mathrm{ppm}$ of $\mathrm{GA}_{3}$ in the $12 / 12$-h light/dark condition. That proportion was markedly lower at $600 \mathrm{ppm}$ and $800 \mathrm{ppm}$ than at $400 \mathrm{ppm}$ (Fig. 1). In the continuous darkness condition, the germination rate was highest at concentrations of 100-600 ppm and was significantly lower at 800 ppm (Fig. 1). Dormancy is a potential problem for most species of the Brassicaceae family. Considerable research on gibberellins as seed germination promoters has shown that application of $\mathrm{GA}_{3}$ to dormant seeds can eliminate their natural chilling requirement (Gashi et al. 2012). The physiological role of $\mathrm{GA}_{3}$ as a promoter of dormant seed germination, through the induction of hydrolytic enzymes, has been documented in a wide range of plant species (Rogis et al. 2004; Zhang et al. 2006; Baskin \& Baskin 2004).
$\mathrm{KNO}_{3}$

Application of $\mathrm{KNO}_{3}$ did not have a significant effect on seed germination (Tab. 1). Among the seeds treated with $\mathrm{KNO}_{3}$, proportional germination was highest $(17.57 \%$, significantly higher than that obtained for the control) for those treated at a concentration of $2 \mathrm{mmol}$ (Fig. 2). Proportional germination did not differ significantly among the various concentrations of $\mathrm{KNO}_{3}$ (Fig. 2). Chauhan et al. (2006b) found that the germination rate of Oriental mustard (Sisymbrium orientale) seeds increased in direct proportion to increasing concentrations of $\mathrm{KNO}_{3}$, although only up to $0.02 \mathrm{M}$, after which it decreased. Promotion and inhibition of germination at low and high concentrations of $\mathrm{KNO}_{3}$ have previously been reported by Wei et al. (2010) and Foley \& Chao (2008), in different plants.

\section{Pre-chilling duration}

The effect of wet pre-chilling on the germination of Capsella bursa-pastoris seeds was significant (Tab. 1). The germination rate increased markedly as the duration of wet pre-chilling increased. After 45 days of wet pre-chilling, $48.51 \%$ of the seeds germinated (Fig. 3). Dry pre-chilling had no significant effect on seed germination (Tab. 1) and did not promote the germination of dormant seeds (Fig. 3). Pre-chilling of many annual plant seeds could be effective in breaking dormancy and stimulating germination (Huang et al. 2004). However, in many plants, wet prechilling has been shown to be more successful than is dry pre-chilling in promoting dormant seed germination and is considered the standard method of inducing germination (Ren \& Guan 2008). Feghahati \& Reese (1994) demonstrated that dry pre-chilling of Echinacea angustifolia was not effective in dormancy breaking. Wet pre-chilling can accelerate seed germination by providing enough moisture to activate the hydraulic enzymes (Nkomo \& Kambizi 2009). Our results show that wet pre-chilling, especially that of longer duration, was considerably more successful than was dry pre-chilling in breaking the dormancy of $C$. bursa-pastoris seeds.

Table 1. ANOVA of the effects of treatments on Capsella bursa-pastoris seed germination

\begin{tabular}{ccc}
\hline Source of variation & $\mathrm{df}$ & MS \\
\hline Gibberllic acid & 5 & $* *$ \\
Potassium nitrate & 5 & $\mathrm{~ns}$ \\
Wet pre-chilling duration & 3 & $* \star$ \\
Dry pre-chilling duration & 3 & $\mathrm{~ns}$ \\
Temperature & 4 & $* *$ \\
pH & 4 & $\mathrm{~ns}$ \\
Sowing depth & 4 & $* *$ \\
\hline
\end{tabular}

"Significant at $\mathrm{P} \leq 0.01$; " ns: Not significant. 


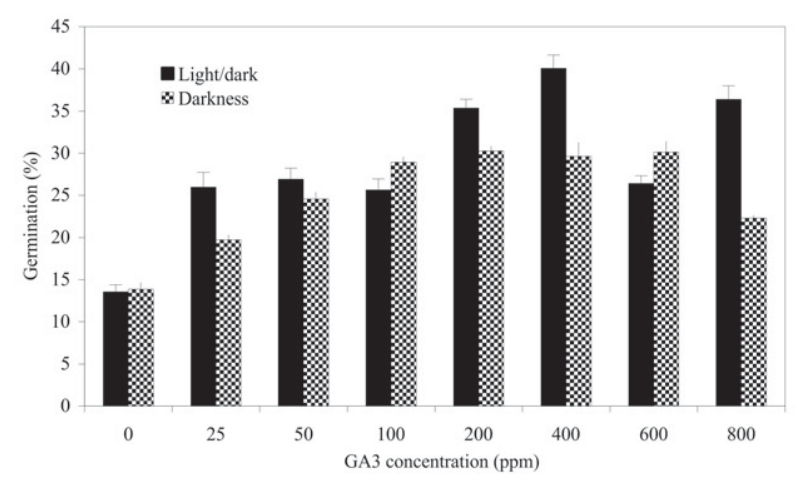

Figure 1. Effects of treatment with gibberellic acid $\left(\mathrm{GA}_{3}\right)$ and light conditions (12/12-h light/dark cycle and continuous darkness) on the germination of dormant Capsella bursa-pastoris seeds incubated for 4 weeks. Vertical bars represent standard errors of the mean.

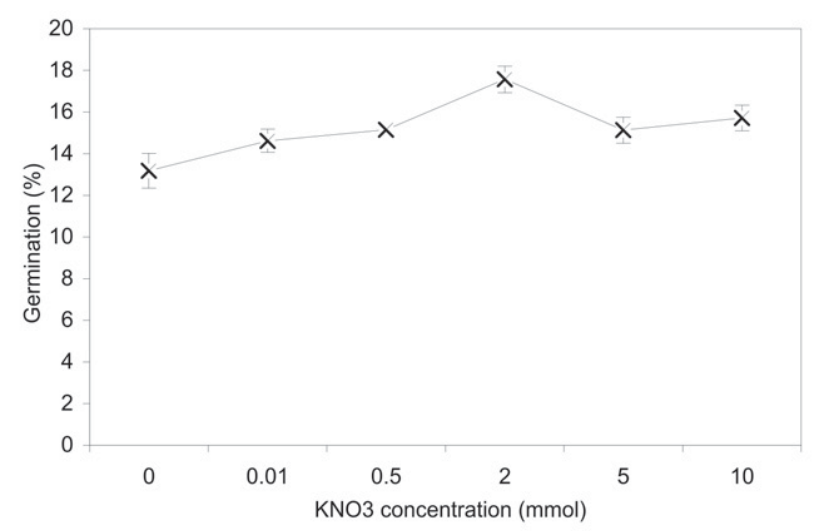

Figure 2. Effect of potassium nitrate $\left(\mathrm{KNO}_{3}\right)$ on the germination of dormant Capsella bursa-pastoris seeds incubated at $25 / 15^{\circ} \mathrm{C}$ (day/night), on a $12 / 12-\mathrm{h}$ light/dark cycle, for 4 weeks. Vertical bars represent standard errors of the mean.

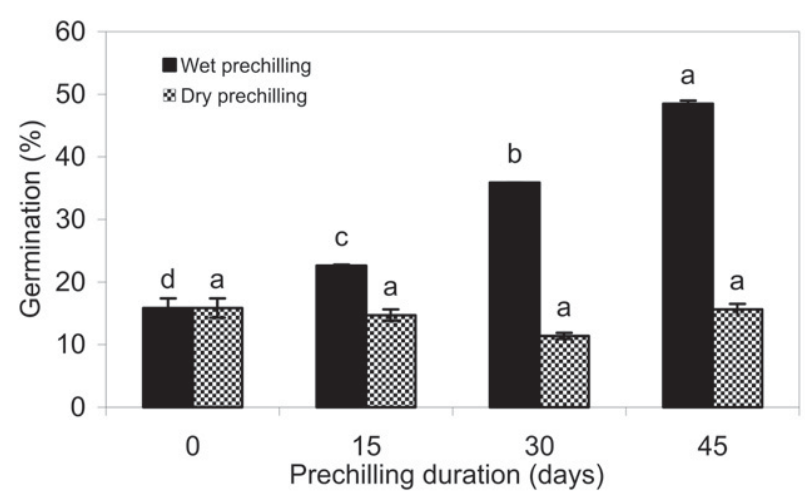

Figure 3. Effect of pre-chilling, by duration, on the germination of dormant Capsella bursa-pastoris seeds incubated at $25 / 15^{\circ} \mathrm{C}$ (day/night), on a $12 / 12-\mathrm{h}$ light/dark cycle, for 4 weeks. Vertical bars represent standard errors of the mean.

\section{Seed germination treatments}

\section{Temperature and light}

The impact of temperature on seed germination was significant, in 12/12-h light/dark and continuous darkness conditions alike (Tab. 1). With increasing temperature, the germination of Capsella bursa-pastoris seed increased markedly in both conditions (Fig. 4). In the 12/12-h light/ dark condition, the germination rate was highest at $30^{\circ} \mathrm{C}$, compared with a range of $20-30^{\circ} \mathrm{C}$ for the continuous darkness condition (Fig. 4). In general, C. bursa-pastoris seeds germinated over a range of $10-30^{\circ} \mathrm{C}$. Within the $10-25^{\circ} \mathrm{C}$ range, seed germination did not differ significantly between the 12/12-h light/dark and continuous darkness conditions. However, at in temperature range from $10^{\circ} \mathrm{C}$ until $25^{\circ} \mathrm{C}$, but in temperature of $30^{\circ} \mathrm{C}$ the germination rate was significantly higher in the 12/12-h light/dark condition (Fig. 4). Temperature and light conditions are important factors in seed germination. The optimum conditions of temperature and light required for the germination of seeds is strongly dependent on the plant species (Egley \& Duke 1985). In the literature we reviewed (e.g., Mulligan \& Bailey 1975; Cousens et al. 1994; Chauhan et al. 2006b), there is evidence that the Brassicaceae seed germination response to temperature and light could be variable. Chauhan et al. (2006c) showed that seed germination of turnipweed (Rapistrum rugosum) was unaffected by variations in temperature but was influenced by the light conditions. However, Cousens et al. (1994) concluded that light conditions have only a slight influence on the germination of $R$. rugosum seeds.

\section{Drought stress}

A nonlinear regression model $\{G(\%)=35.01 /[1+$ $\left.\left.(x / 0.24)^{1.97}\right], R^{2}=0.971\right\}$ was fitted to seed germination (\%) values obtained at different osmotic potentials (Fig. 5). Drought stress greatly reduced seed germination of Capsella bursa-pastoris. As can be seen in Fig. 5, the osmotic potential required for $50 \%$ inhibition of maximum germination was calculated by the model at $-0.24 \mathrm{MPa}$. Germination at -1 MPa reached zero, indicating that seeds of $C$. bursa-pastoris are intolerant to high drought stress conditions (Fig. 5). According to our review of the literature, germination tolerance to drought stress varies among Brassicaceae species. Ray et al. (2005) reported that seeds of London rocket (Sisymbrium irio L.) germinated up to an osmotic potential of $-1.2 \mathrm{MPa}$.

\section{Salt stress}

Germination of Capsella bursa-pastoris seeds was decreased by increasing $\mathrm{NaCl}$ concentrations $\left(\mathrm{y}=34.462 \mathrm{e}^{-0.0146 \mathrm{x}}\right.$, $\left.\mathrm{R}^{2}=0.90\right)$. There was no significant change in seed germination at $\mathrm{NaCl}$ concentrations from $10 \mathrm{mM}$ to $80 \mathrm{mM}$. At high 


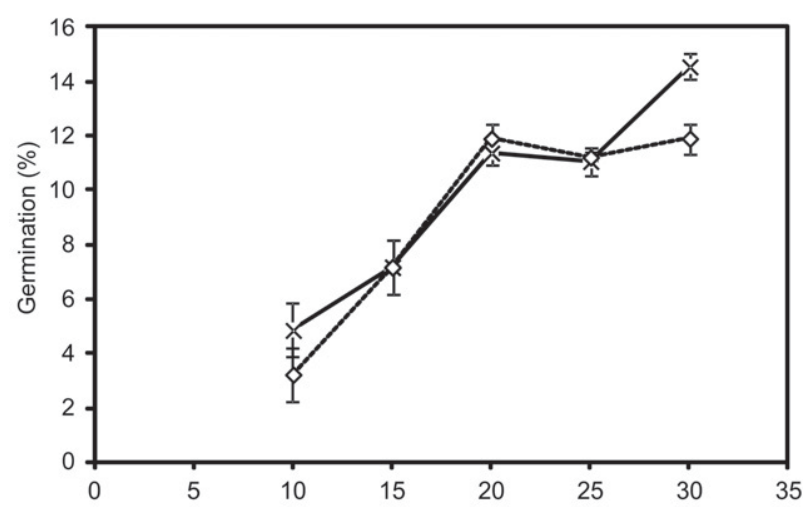

Figure 4. Effects of constant temperature and light conditions (12/12-h light/ dark cycle and continuous darkness) on the germination of dormant Capsella bursa-pastoris seeds incubated for 4 weeks. Vertical bars represent standard errors of the mean.

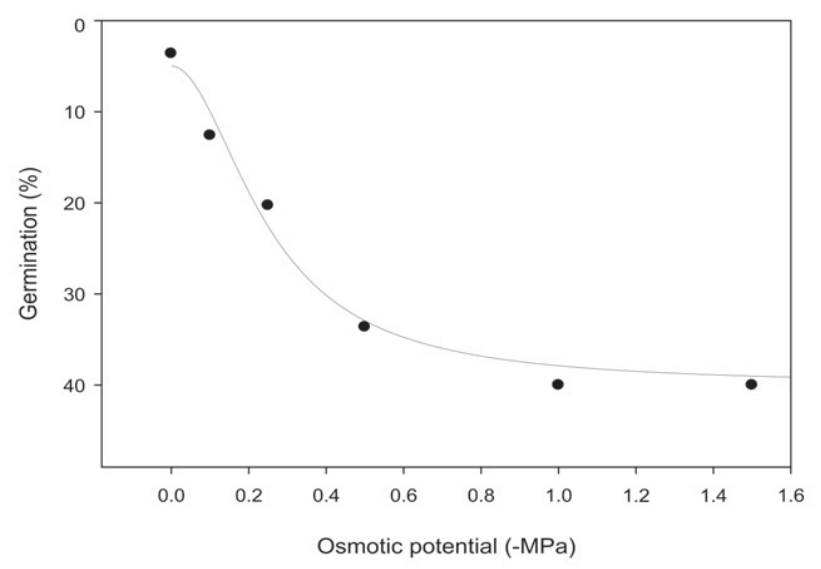

Figure 5. Effect of drought stress on the germination of dormant Capsella bursa-pastoris seeds. The line represents the functional three-parameter logistic model $-G(\%)=G_{\max } /\left[1+(x / x 50)^{\mathrm{G}_{\text {rate }}}\right]-$ fitted to the data.

salinity $(160 \mathrm{mM}), 2.63 \%$ of seeds germinated that showing the potential of C. bursa-pastoris seeds to germinate in conditions of high salinity (Fig. 6). Other authors have also reported a salt stress-related reduction in the germination of seeds of different plant species (Ray et al. 2005; Mulligan \& Bailey 1975; Chauhan et al. 2006b; Gordin et al. 2012). In northern Iran, which is a main habitat of C. bursa-pastoris, conditions of high salinity can occur in fields and orchards near the seashore because of high depletion of ground water.

$\mathrm{pH}$

The effect of $\mathrm{pH}$ on the germination of Capsella bursapastoris seed was not significant (Tab. 1). Figure 7 shows that germination of $C$. bursa-pastoris seeds occurred in a wide range of $\mathrm{pH}$ values (from 3 to 11). The germination rate was significantly higher at $\mathrm{pH} 3$ and $\mathrm{pH} 9$ than at $\mathrm{pH}$ 7. According to our results, $\mathrm{pH}$ is not a critical factor ger-

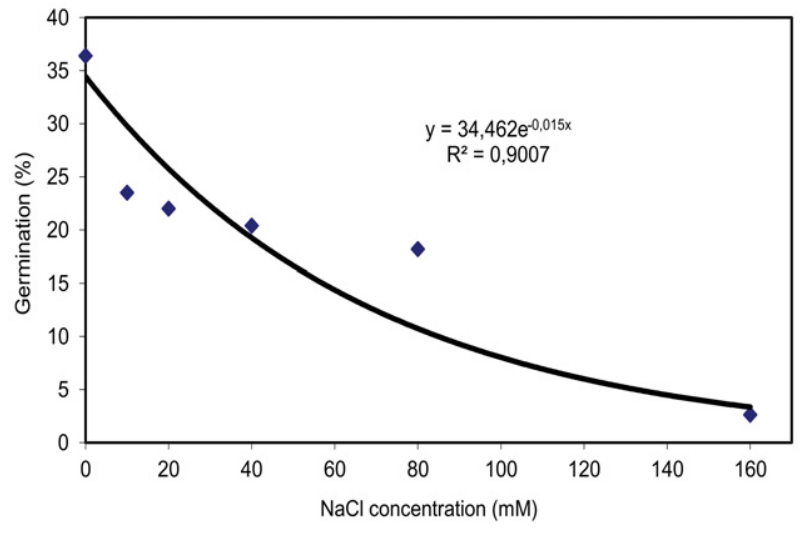

Figure 6. Effect of salt stress on the germination of dormant Capsella bursapastoris seeds incubated at $25 / 15^{\circ} \mathrm{C}$ (day/night), on a $12 / 12$-h light/dark cycle, for 4 weeks.

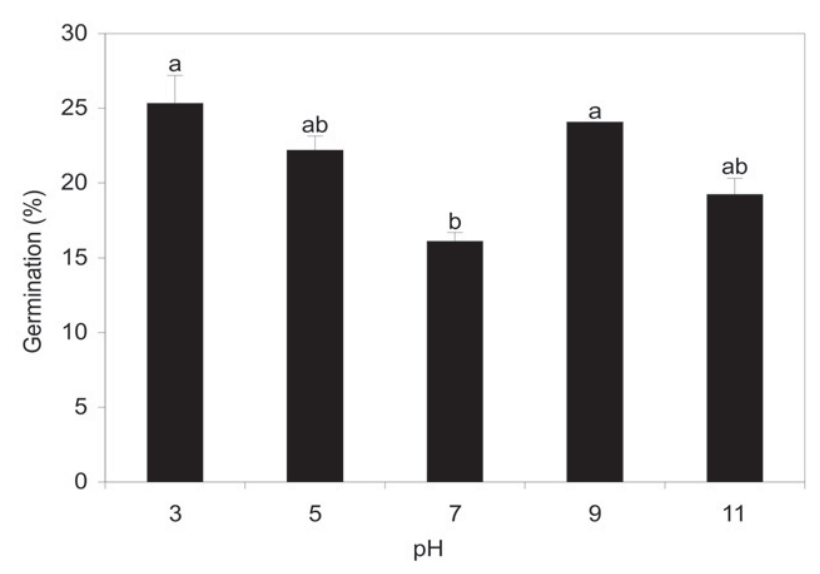

Figure 7. Effect of $\mathrm{pH}$ on the germination of dormant Capsella bursa-pastoris seeds incubated at $25 / 15^{\circ} \mathrm{C}$ (day/night), on a $12 / 12$-h light/dark cycle, for 4 weeks. Vertical bars represent standard errors of the mean.

mination of C. bursa-pastoris. Similarly, Ray et al. (2005), Chauhan et al. (2006b) and Chauhan et al. (2006c) have been reported Brassicaceae seeds germinated in a broad range of $\mathrm{pH}$. These data suggest that $\mathrm{pH}$ is not a limiting factor for Brassicaceae family seed germination. In addition, other authors (e.g., Zhou et al. 2005; Fani Yazdi et al. 2013; Rezvani \& Fani Yazdi 2013) have suggested that pH is not a limitation for germination of seed in different plant families.

\section{Sowing depth}

The effect of sowing depth on Capsella bursa-pastoris seedling emergence was significant (Tab. 1). Seedling emergence decreased markedly in parallel with increasing seed sowing depth (Fig. 8). The highest rates of seed germination and seedling emergence were observed for seed scattered on the soil surface. When the sowing depth was $4 \mathrm{~cm}$, no seedlings emerged (Fig. 8). Our results suggest that light 


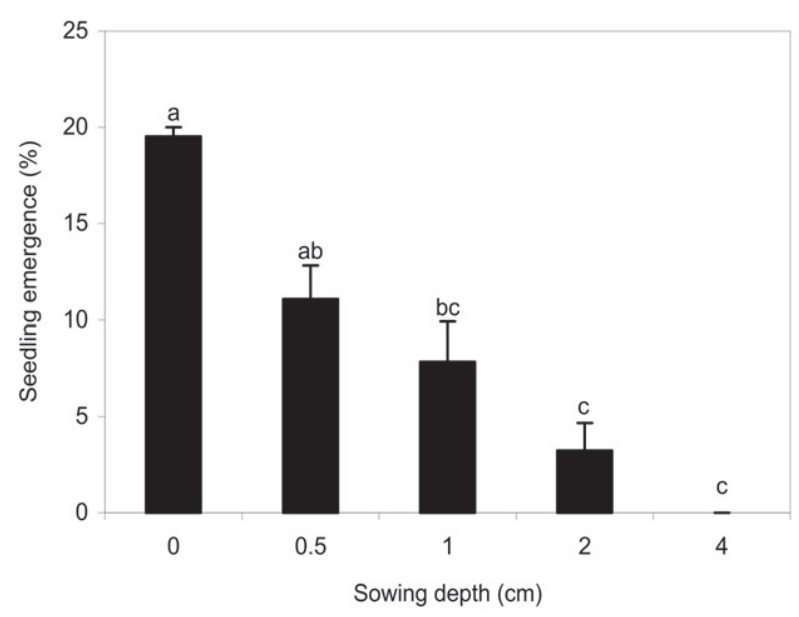

Figure 8. Effect of sowing depth on seedling emergence in Capsella bursa-pastoris seeds incubated at $25 / 15^{\circ} \mathrm{C}$ (day/night), on a $12 / 12$-h light/dark cycle, for 4 weeks. Vertical bars represent standard errors of the mean.

is a critical factor for the germination of C. bursa-pastoris seed. Similarly, Chauhan et al. (2006a; 2006b) showed that, in small-seeded Brassicaceae, the rate of seedling emergence decreases in proportion to sowing depth. Our results indicate that sowing C. bursa-pastoris seeds to a depth $\geq 4 \mathrm{~cm}$ can result in a significant reduction in the density of this species in next crop.

\section{Conclusions}

We found that treatment with $\mathrm{GA}_{3}$ at a concentration of 400 ppm strongly promoted germination of Capsella bursapastoris seeds in the 12/12-h light/dark condition. Among the seeds treated with $\mathrm{KNO}_{3}$, proportional germination was highest (and significantly higher than that observed for the control) for those treated at a concentration of $2 \mathrm{mmol}$. In addition, wet pre-chilling for 45 days was more successful in breaking the dormancy of C. bursa-pastoris seeds than was dry pre-chilling, treatment with $\mathrm{GA}_{3}$, and treatment with $\mathrm{KNO}_{3}$ (17.57\%). We found that C. bursa-pastoris seeds germinated at a range of $10-30^{\circ} \mathrm{C}$ and at $\mathrm{pH}$ values between 3 and 11 , indicating that the latter is not a critical factor. We also found that C. bursa-pastoris seed germination rates decreased in parallel with increases in the levels of salt and drought stress. However, our data suggest that C. bursapastoris seeds can germinate at high salinity. Moreover, we found that sowing depth (i.e., light) is a critical factor for the germination of C. bursa-pastoris seeds.

\section{Acknowledgments}

The authors are grateful for the financial support provided by the Office of the Vice-Chancellor for Research at the Qaemshahr Branch of Islamic Azad University, in Qaemshahr, Iran.

\section{References}

Baskin, J.M. \& Baskin, C.C. 1989. Germination responses of buried seeds of Capsella bursa-pastoris exposed to seasonal temperature changes. Weed Research 29:205-212.

Baskin, J.M. \& Baskin, C.C. 2004. A classification system for seed dormancy. Seed Science Research 14:1-16.

Bewley, D.J. \& Black. M. 1994. Seeds-physiology of development and germination. Plenum, New York, USA.

Bouwmeester, H.J. \& Karssen, C.M. 1992. The Dual Role of Temperature in the Regulation of the Seasonal-Changes in Dormancy and Germination of Seeds of Polygonum persicaria L. Oecologia 90:88-94.

Bouwmeester, H.J. \& Karssen, C.M. 1993. Annual Changes in Dormancy and Germination in Seeds of Sisymbrium-Officinale (L.) Scop. New Phytologist 124:179-191.

Chachalis, D. \& Reddy, K.N. 2000. Factors affecting Campsis radicans seed germination and seedling emergence. Weed Science 48:212-216.

Chauhan, B.S.; Gill, G. \& Preston, C. 2006a. Seedling recruitment pattern and depth of recruitment of 10 weed species in minimum tillage and no-till seeding systems. Weed Science 54:891-897.

Chauhan, B.S.; Gill, G. \& Preston, C. 2006b. Influence of environmental factors on seed germination and seedling emergence of Oriental mustard (Sisymbrium orientale) Weed Science 54:1025-1031.

Chauhan, B.S.; Gill, G. \& Preston, C. 2006c. Factors affecting turnipweed (Rapistrum rugosum) seed germination in southern Australia. Weed Science 54(6):1032-1036.

Chauhan, B.S. \& Johnson, D.E. 2010. The role of seed ecology in improving weed management strategies in the tropics. Advanced Agronomy 105:221-262.

Cousens, R.; Armas, G. \& Baweja, R. 1994. Germination of Rapistrum rugosum (L.) All. from New South Wales, Australia. Weed Research 34:127-135.

Egley, G.H. \& Duke. S.O. 1985. Physiology of weed seed dormancy and germination. Pages 27-64 in S. O. Duke, ed. Weed Physiology. Volume I. Reproduction and Ecophysiology. Boca Raton, FL, CRC, USA.

Fani Yazdi, S.A.; Rezvani, M.; Rashed Mohassel, M.H. \& Ghanizadeh, H. 2013. Factors affecting seed germination and seedling emergence of sheep sorrel (Rumex acetosella). Romanian Agricultural Research 30:373-380.

Feghahati, S.M.J. \& Reese, R. N. 1994. Ethylene, light and prechill enhanced germination of Echinacea angustifolia seeds. Journal of American Society of Horticultural Science 119:853-858.

Foley, M.E. \& Chao, W.S. 2008. Growth regulators and chemicals stimulate germination of leafy spurge (Euphorbia esula) Seeds. Weed Science 56:516-522.

Gashi, B.; Abdullai, K.; Mata, V. \& Kongjika, E. 2012. Effect of gibberellic acid and potassium nitrate on seed germination of the resurrection plants Ramonda serbica and Ramonda nathaliae. African Journal of Biotechnology 11(20):4537-4542.

Gordin, C.R.B.; Marques, R.F.; Masetto, T.E. \& Souza, L.C.F. 2012. Salt stress on seeds germination and seedlings development of niger (Guizotia abyssinica (L.f.) Cass.). Acta Botanica Brasilica 26: 966-972.

Holm, G.L.; Pancho, V.J.; Herberger, J.P. \& Plucknett, L.D. 1979. A Geographical Atlas of World Weeds. Wiley-Interscience Publications, New York, USA.

Huang, Z.Y.; Dong, M. \& Gutterman, Y. 2004. Caryopsis dormancy, germination and seedling emergence in sand, of Leymus racemosus (Poaceae), A perennial sand-dune grass inhabiting the Junggar Basin of Xinjiang, China. South African Journal of Botany 52:519-528.

Karimi, H., 2001. Weeds of Iran. Center for University Publications. Iran.

Kleemann, S.G.L; Chauhan, B.S. \& Gill, G.S. 2007. Factors affecting seed germination of perennial wall rocket (Diplotaxis tenuifolia) in southern Australia. Weed Science 55:481-485.

Koger, C.H.; Reddy, K.N. \& Poston, D.H. 2004. Factors affecting seed germination, seedling emergence, and survival of texasweed (Caperonia palustris). Weed Science 52:989-995.

Michel, B.E. 1983. Evaluation of the water potentials of solutions of polyethylene glycol 8000 both in the absence and presence of other solutes. Plant Physiology 72:66-70.

Mulligan, G.A. \& Bailey, L.G. 1975. The biology of Canadian weeds, 8: Sinapis arvensis L. Canadian Journal of Plant Science 55:171-183. 
Nkomo, M. \& Kambizi, L. 2009. Effects of pre-chilling and temperature on seed germination of Corchorus olitorius L. (Tiliaceae), a wild leafy vegetable. African Journal of Biotechnology 8:1078-1081.

Peters, J. 2000. Association of Official Seed Analysis Tetrazolium Testing Handbook, Contribution No. 29, 1st Revision. Lincoln, NE: Association of Official Seed Analysis.

Ray, J.; Creamer, R.; Schroeder, J. \& Murray, L. 2005. Moisture and temperature requirements for London rocket (Sisymbrium irio) emergence. Weed Science 53:187-192.

Ren, Y.Q. \& Guan, K.Y. 2008. Effects of moist chilling and GA applications on seed germination of three Pedicularis species from Yunan, China. Seed Science Technology 36:225-229.

Rezvani, M. \& Fani Yazdi S.A. 2013. Factors affecting seed germination of black nightshade (Solanum nigrum). Acta Botanica Hungarica 55(3-4):397-408.

Rogis, C.; Gibson, L.R; Knapp, A.D. \& Horton, R. 2004. Enhancing germination of eastern gama grass seed with stratification and gibberellic acid. Crop Science 44:549-552.
Toorop, P.E.; Begg, G.S.; Wishart, J. \& Iannetta, P.P.M. 2008. Germination characters and myxospermy of shepherds purse (Capsella bursapastoris (L.) Medic) time to flowering variants. Polish Journal Natural Sciences 5:101.

Toorop, P.E.; Cuerva1, R.C.; Begg, G.S.; Locardi, B.; Squire G.R. \& Iannetta, P.P.M. 2011. Co-adaptation of seed dormancy and flowering time in the arable weed Capsella bursa-pastoris (shepherd's purse). Annals of Botany. 1-9.

Wei, S.; Zhang, C.; Chen, X.; Li, X.; Sui, B.; Huang, H.; Cui, H.; Liu, Y.; Zhang, M. \& Guo, F. 2010. Rapid and effective methods for breaking seed dormancy in buffalobur (Solanum rostratum). Weed Science 58:141-146.

Zhang, W.D.; Bi, J.J.; Ning, T.Y.; Liu, G.S. \& He, M.R. 2006. Effect of temperature, light and other treatments on seed germination of Leymus chinensis. Plant Science 86:67-73.

Zhou, J.; Deckard, E.L. \& Ahrens, W.H. 2005. Factors affecting germination of hairy nightshade (Solanum sarrachoides) seeds. Weed Science 53:41-45. 